\title{
Ecology of the Oceanic Rim: Pelagic Eels as Key Ecosystem Components
}

Jennifer N. Feagans-Bartow

Florida Atlantic University

Tracey Sutton

Nova Southeastern University, tsutton1@nova.edu

Find out more information about Nova Southeastern University and the Halmos College of Natural Sciences and Oceanography.

Follow this and additional works at: https://nsuworks.nova.edu/occ_facarticles

Part of the Marine Biology Commons, and the Oceanography and Atmospheric Sciences and Meteorology Commons

\section{NSUWorks Citation}

Jennifer N. Feagans-Bartow and Tracey Sutton. 2014. Ecology of the Oceanic Rim: Pelagic Eels as Key Ecosystem Components .Marine Ecology Progress Series : 257 -266. https://nsuworks.nova.edu/occ_facarticles/532.

This Article is brought to you for free and open access by the Department of Marine and Environmental Sciences at NSUWorks. It has been accepted for inclusion in Marine \& Environmental Sciences Faculty Articles by an authorized administrator of NSUWorks. For more information, please contact nsuworks@nova.edu. 


\title{
Ecology of the oceanic rim: pelagic eels as key ecosystem components
}

\author{
Jennifer N. Feagans-Bartow ${ }^{1,3, *}$, Tracey T. Sutton ${ }^{2}$ \\ ${ }^{1}$ Harbor Branch Oceanographic Institute, Florida Atlantic University, Fort Pierce, Florida 34946, USA \\ ${ }^{2}$ Nova Southeastern University Oceanographic Center, Dania Beach, Florida 33004, USA \\ ${ }^{3}$ Present address: Department of Biological Science, Indian River State College, Fort Pierce, Florida 34981, USA
}

\begin{abstract}
Although $92 \%$ of the total volume of the world's oceans occurs below a depth of $200 \mathrm{~m}$, our understanding of deep-sea food webs lags far behind that of continental shelves. In particular, little is known about the exchange of biomass at the interface of continental margins and deep-sea ecosystems. Recent studies suggest that the transport of organic matter from continental shelves may influence deep-sea ecosystems more than previously thought. Here, we present results of a pelagic nekton survey along the southern slope of Georges Bank, NW Atlantic, a transition area between coastal and deep-sea environments. Specimens were collected as part of the Census of Marine Life program Gulf of Maine Area project. Macrocrustacea (primarily sergestid shrimps and large euphausiids) dominated the total nekton (all taxa) numbers and biomass. Of the 85 deep-pelagic fish species collected during this cruise, the slender snipe eel Nemichthys scolopaceus (Anguilliformes: Nemichthyidae) ranked first in biomass and second in abundance. Microscopic analysis of $N$. scolopaceus gut contents revealed a predominance of large euphausiid and decapod prey. Other abundant potential prey, such as zooplankton, fish, and cephalopods, were absent from the diet, suggesting discriminatory feeding. Considering the relative biomass dominance of sergestid shrimps, large euphausiids, and pelagic eels in this system, the ecological interaction described here likely represents a major trophic pathway in this and similar 'oceanic rim' ecosystems.
\end{abstract}

KEY WORDS: Continental margin - Mesopelagic - Pelagic eel · Trophic ecology · Food webs · Gulf of Maine Resale or republication not permitted without written consent of the publisher

\section{INTRODUCTION}

The deep-sea environment, comprising $\sim 92 \%$ of the total ocean volume (Haedrich 1997), is the largest living space on Earth, totaling more than $1.3 \times$ $10^{9} \mathrm{~km}^{3}$ (Horn 1972, Robison 2004). It is also one of the least known environments (Webb et al. 2010). In order to address this lack of knowledge, several Census of Marine Life (www.coml.org) field projects were developed between 2000 and 2010. One such project, the Gulf of Maine Area (GoMA) program (www.gulfofmaine-census.org), considered the pelagic community structure of the southern slope of
Georges Bank, an 'oceanic rim' ecosystem (sensu Merrett 1986). Some evidence suggests that mesopelagic micronekton communities in these ecosystems differ in species composition, abundance, and diversity from those of adjacent oceanic ecosystems (Reid et al. 1991). Aggregations of meso- and bathypelagic organisms along continental slopes and other abrupt topography have also been reported (Porteiro \& Sutton 2007, Gartner et al. 2008, Sutton et al. 2008). Certain mesopelagic fishes, specifically, may often occur in large numbers when associated with these slope ecosystems (Reid et al. 1991). Marshall \& Merrett (1977) emphasized the likely trophic significance 
of enhanced abundances of mesopelagic animals in slope ecosystems, though little is known of the transition in carbon flow and energy between coastal and oceanic environments (Company et al. 2008). In a recent synopsis of the GoMA, Kelly et al. (2010, p. 2) state:

Currently, the number of different species inhabiting the deep-sea Gulf of Maine region, their distribution across habitats, or their connection to the faunal communities of the continental shelf is poorly understood.

In this paper, we describe the trophic ecology of the biomass-dominant mesopelagic fish over the southern slope of Georges Bank, the slender snipe eel Nemichthys scolopaceus (Anguilliformes: Nemichthyidae).

Nemichthys scolopaceus Richardson 1848 (Fig. 1a) is cosmopolitan in tropical and temperate seas, spanning the Atlantic, Indian, and Pacific Oceans between $55^{\circ} \mathrm{N}$ to $50^{\circ} \mathrm{S}$ (Bilecenoglu et al. 2006). After leptocephalus transformation, slender snipe eels are thought to inhabit the mesopelagic and bathypelagic zones exclusively (Nielsen \& Smith 1978, Karmovskaya 1982, Fishelson 1994, Inoue et al. 2010), most commonly between 200 and 1000 m (Smith \& Tighe
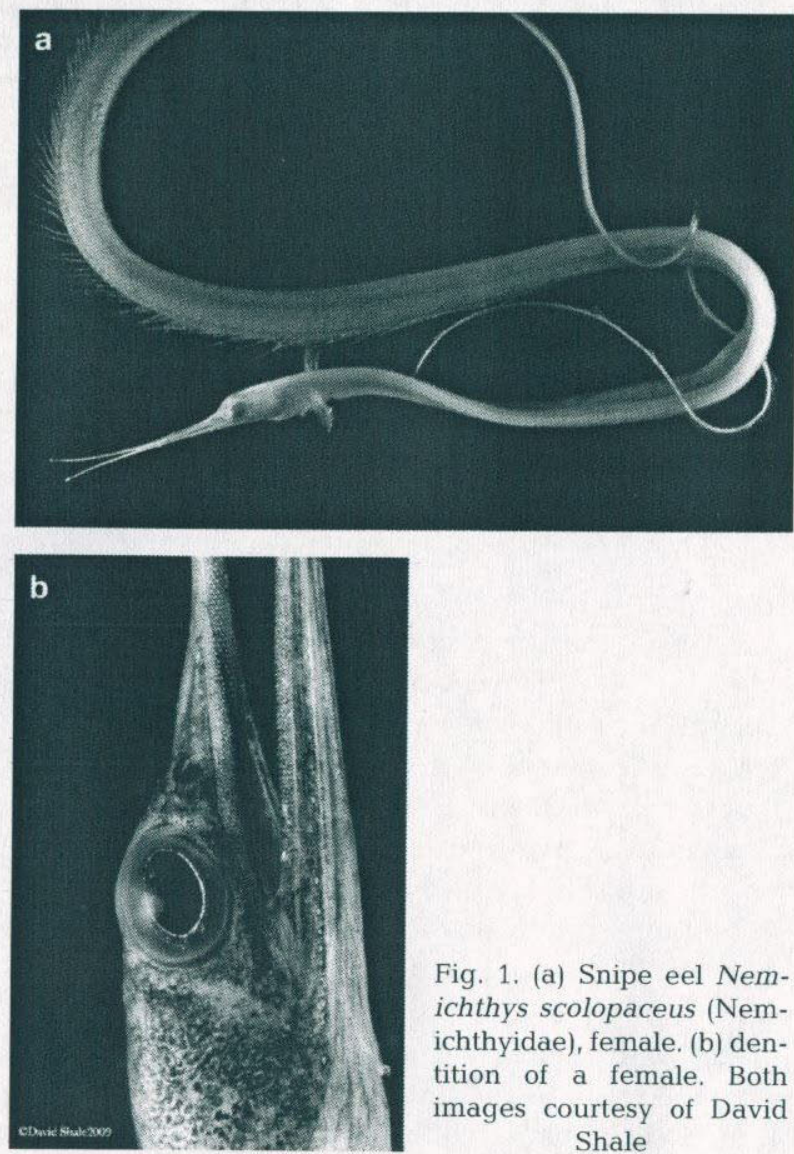

Fig. 1. (a) Snipe eel Nemichthys scolopaceus (Nemichthyidae), female. (b) dentition of a female. Both images courtesy of David Shale
2002). Members of the family Nemichthyidae do not show strict diel migration patterns, though $N$. scolopaceus specifically is known to undergo a very active continual vertical migration in association with prey capture (Karmovskaya 1982). The majority of prior studies of Nemicththys scolopaceus focused on systematics, distribution, or life history (Beebe \& Crane 1937, Nielsen \& Smith 1978, Castonguay \& McCleave 1987, Smith \& Nielsen 1989, Fishelson 1994, Miller \& McCleave 1994, Inoue et al. 2010). There is very little research addressing their trophic ecology (Mead \& Earle 1970, Gartner 1981, Appelbaum 1982, Bowman et al. 2000). Furthermore, none of these studies have focused exclusively on $N$. scolopaceus feeding, and the majority of trophic information presented thus far has been based on rather small sample sizes. The overall purpose of this study was to quantify the abundance and feeding of a dominant mesopelagic predatory fish in a shelf-break ecosystem in order to better understand the energy dynamics occurring along the oceanic rim. The topics addressed include prey composition, prey quantity, spatiotemporal feeding dynamics, and diet specialization.

\section{MATERIALS AND METHODS}

\section{Study site}

Samples were collected from 18 to 23 May 2004 aboard the NOAA research vessel 'Delaware II' along the southern flank of the Georges Bank area as part of the Census of Marine Life Gulf of Maine Area field project. Georges Bank is located at the end of the continental shelf, roughly $100 \mathrm{~km}$ off the northeast US coast $\left(40^{\circ}\right.$ to $42^{\circ} \mathrm{N}, 71^{\circ}$ to $\left.66^{\circ} \mathrm{W}\right)$. It is $\sim 150 \mathrm{~km}$ wide and $280 \mathrm{~km}$ long, runs roughly east-west, and the southern edge is transected by at least 15 submarine canyons (Fig. 2). These canyons can be thought of as highly modified areas of the continental slope, which show a more complex fauna, topography, and hydrography than the surrounding slope area (Cooper et al. 1987).

\section{Trawling and sample handling}

A modified International Young Gadoid Pelagic Trawl (IYGPT; see Moore et al. 2001 for details) was used to collect micronektonic $(20 \mathrm{~mm}-20 \mathrm{~cm})$ and nektonic $(>20 \mathrm{~cm}$ ) midwater organisms (nekton hereafter). This net was retrofitted with deepwater floats and a $4 \mathrm{~mm}$ mesh liner (stretched). The mouth area 


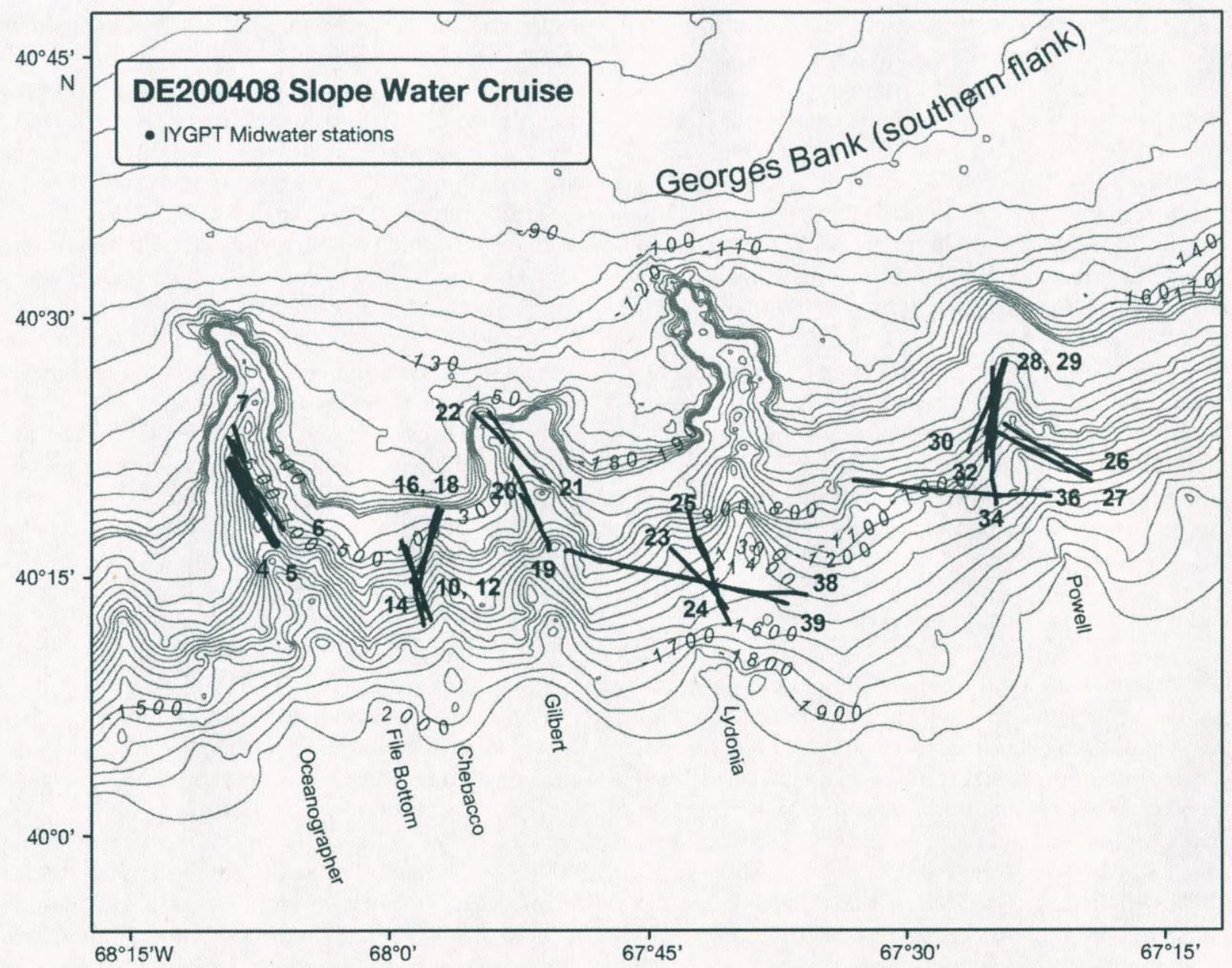

Fig. 2. Bathymetric map (m) of the sample site and locations of trawl tracks

measured $10 \times 10 \mathrm{~m}$ when towed at 2.5 knots with a $50 \mathrm{~m}$ doorspread. The trawl doors used were $1.8 \mathrm{~m}^{2}$ area USA Jet suberkrub-type midwater doors. Fifteen trawl samples were taken in total, 11 during daylight and 4 during nighttime (Table 1), fished open from the surface to the target depths (400-700 m) and retrieved. Net depth $(Z)$ was measured using a Scanmar acoustic link sensor fixed to the headrope of the trawl and recorded using the Hyperterminal feature of Microsoft Windows. Trawl tracks were oriented within canyons and along open slope topography (Fig. 2). Trawl catches were standardized for unit effort (no. ind. or biomass $\mathrm{h}^{-1}$ ).
Table 1. Georges Bank trawl data from 2004 listed by station number. Maximum net depth was measured using a Scanmar acoustic link depth sensor attached to the headrope of the trawl

\begin{tabular}{|lccccr|}
\hline Station & Date & $\begin{array}{c}\text { Starting } \\
\text { Lat }(\mathrm{N}) / \text { Long }(\mathrm{W})\end{array}$ & $\begin{array}{c}\text { Solar } \\
\text { cycle }\end{array}$ & $\begin{array}{c}\text { Max net } \\
\text { depth }(\mathrm{m})\end{array}$ & $\begin{array}{c}\text { Length of } \\
\text { trawl (min) }\end{array}$ \\
\hline 4 & 19 May & $40^{\circ} 18^{\prime} / 68^{\circ} 07^{\prime}$ & Day & 670 & 110.23 \\
5 & 19 May & $40^{\circ} 23^{\prime} / 68^{\circ} 09^{\prime}$ & Night & 620 & 70.22 \\
6 & 19 May & $40^{\circ} 19^{\prime} / 68^{\circ} 07^{\prime}$ & Night & 565 & 30.00 \\
10 & 20 May & $40^{\circ} 14^{\prime} / 67^{\circ} 58^{\prime}$ & Day & 480 & 30.02 \\
12 & 20 May & $40^{\circ} 17^{\prime} / 67^{\circ} 59^{\prime}$ & Day & 550 & 101.27 \\
14 & 20 May & $40^{\circ} 13^{\prime} / 67^{\circ} 58^{\prime}$ & Night & 490 & 29.68 \\
16 & 21 May & $40^{\circ} 18^{\prime} / 67^{\circ} 56^{\prime}$ & Day & 470 & 105.67 \\
19 & 21 May & $40^{\circ} 19^{\prime} / 67^{\circ} 52^{\prime}$ & Day & 505 & 88.72 \\
20 & 21 May & $40^{\circ} 21^{\prime} / 67^{\circ} 52^{\prime}$ & Day & 450 & 72.10 \\
23 & 22 May & $40^{\circ} 15^{\prime} / 67^{\circ} 42^{\prime}$ & Day & 435 & 29.98 \\
24 & 22 May & $40^{\circ} 15^{\prime} / 67^{\circ} 41^{\prime}$ & Day & 450 & 29.95 \\
25 & 22 May & $40^{\circ} 18^{\prime} / 67^{\circ} 42^{\prime}$ & Day & 470 & 87.52 \\
26 & 22 May & $40^{\circ} 21^{\prime} / 67^{\circ} 21^{\prime}$ & Night & 470 & 30.00 \\
27 & 23 May & $40^{\circ} 23^{\prime} / 67^{\circ} 24^{\prime}$ & Day & 500 & 108.73 \\
28 & 23 May & $40^{\circ} 23^{\prime} / 67^{\circ} 25^{\prime}$ & Day & 450 & 29.92 \\
\hline
\end{tabular}


Trawl samples were sorted on board immediately after trawl retrieval. All fish species were counted, measured, and weighed using a Marel motioncompensating scale, and then either fixed or frozen aboard the ship. Crustacean taxa were weighed by lot and a subsample was preserved for enumeration and taxonomic determination. All catch weights are presented as wet weight in grams (WWg). Specimens were preserved in a $10 \%$ buffered formalin:seawater mixture, and then transferred to a $70 \%$ ethanol solution. Large-volume fish samples were frozen onboard in lots by sample number, and later preserved. As for other taxa, high-speed midwater trawls do not quantitatively sample gelatinous fauna, as they are often extruded through the mesh, therefore, very little gelatinous material was recovered. Mesopelagic cephalopods were rare, and thus omitted from analysis.

\section{Diet analysis}

A subset of the total number of Nemichthys scolopaceus specimens was selected for dissection, with the primary selection criteria being size (equal representation across size range) and time of capture (maximum representation across the $24 \mathrm{~h}$ cycle), in order to assess ontogenetic effects and feeding chronology, respectively (see below). This species exhibits strong sexual and ontogenetic dimorphism. As juveniles, all individuals have non-occlusible jaws bearing small villiform teeth (Fig. 1b). Upon reaching sexual maturity, males undergo a striking transformation. They experience a complete loss of teeth, the jaws radically shorten (Smith \& Nielsen 1989) and develop tubular anterior nares (Nielsen \& Smith 1978, Anonymous 1979), while females remain morphologically similar to juveniles. The feeding data presented in this paper represent those of juveniles and females. No males were collected during sampling.

Prior to dissection, pre-anal length (PL), defined as the distance from the posterior edge of the eye orbit to the anus, was measured to the nearest millimeter. Total length (TL) proved unreliable as both the jaws and caudal filaments are fragile and were often broken. Each study specimen was weighed to the nearest $0.01 \mathrm{~g}$ using an Acculab VI-I mg balance with a readability of $0.001 \mathrm{~g}$. This measure of wet weight $(\mathrm{WW})$ can be considered an underestimate because each time a specimen is frozen, thawed, fixed, and/or placed in ethanol, some percentage of water and organic matter is likely lost (Wiebe et al. 1975, Sutton \& Hopkins 1996). Given that all taxa were subjected to the same methodol- ogy, predator/prey biomass comparisons should be relatively unaffected.

For gut content analysis, the entire digestive tract was removed; the stomach and intestines were separated and opened individually. All large food particles and identifiable prey parts were then placed in separate vials of $70 \%$ ethanol, whereas smaller particles were mounted on glass slides for later identification. Prey items were identified to the lowest possible taxonomic level, either from whole prey or from diagnostic hard structures. The total number of prey was estimated by counting the total number of diagnostic structures and dividing by the appropriate number of structures per animal (e.g. all eyes counted and total divided by 2 to estimate number of prey). In cases where diagnostic hard structures could not be counted, a prey number of 1 was assigned to that prey category.

\section{Feeding chronology}

In order to determine when, and how many times, eels feed relative to the diel cycle, excised stomachs were ranked on a scale of stomach fullness from 0 to 4 , with $0=$ empty, $1=$ traces of prey present, $2=a$ partially to half-filled stomach, $3=$ mostly full but not stretched, and $4=\mathrm{a}$ full and stretched stomach. Additionally, every prey item recovered was ranked on a scale of 1 to 4 , representing the degree of digestion. The scale was as follows: $1=$ no visible sign of digestion, prey whole and complete; $2=$ prey partially digested, not complete; 3 = prey highly digested, only pieces remaining; and $4=$ almost completely digested, only traces remaining.

\section{Feeding selectivity}

Ivlev's electivity index $(E)$ was calculated to indicate the density-dependence of prey selection by Nemichthys scolopaceus. This index has been successfully used to determine the prey selectivity of a plethora of marine and freshwater fishes (e.g. Islam et al. 2006, Ribeiro \& Nuñer 2008). Ivlev's electivity index is defined as:

$$
E=(r-p) /(r+p)
$$

where $r=$ percentage of a given prey taxon in the diet and $p=$ percentage of that prey item in the environment. Values range from -1 to +1 , with all values greater than zero indicating an overrepresentation of the prey, zero indicating ambient representation, and 
all values less than zero indicating underrepresentation of the prey within the predator's diet (Ivlev 1961, Strauss 1979, Gras \& Saint-Jean 1982, Mcllwain \& Jones 1997, Alwany et al. 2003).

\section{RESULTS}

\section{Pelagic nekton assemblage composition and abundance}

Macrocrustaceans (decapod crustacea, mysids, lophogastrids, and large euphausiids) dominated the nekton assemblage (Table 2), both in terms of numbers $(96.1 \%)$ and biomass $(71.4 \%)$. The dominant components of the macrocrustacean assemblage were decapod crustaceans $(57.3 \%$ abundance, $78.7 \%$ WWg), primarily Sergestes arcticus, followed by euphausiids, mainly Meganyctiphanes norvegica. Lophogastrids of the genus Gnathophausia were occasionally taken, but were much less abundant than the other 2 taxa.

A total of 85 fish species, ranging from 1 to 4904 individuals, were collected by midwater sampling. Nemichthys scolopaceus ranked first in total fish biomass (1628.7 WWg $\mathrm{h}^{-1}$ ) and second in abundance (130.1 ind. $\mathrm{h}^{-1}$ ), trailing only the glacier lanternfish Benthosema glaciale (Table 3). After these 2 species,

Table 2. Micronekton/nekton assemblage abundance (total ind. for all trawls) and biomass (total wet wt for all trawls, g) collected along the southern slope of Georges Bank

\begin{tabular}{|lrrrr|}
\hline & Abundance & $\%$ & Biomass & $\%$ \\
\hline Fish & 9865 & 3.9 & 54116.3 & 28.5 \\
Decapod & 138495 & 55.0 & 106649.2 & 56.2 \\
Euphausiid & 103094 & 41.0 & 28725.0 & 15.1 \\
Mysid & 304 & 0.1 & 144.2 & 0.1 \\
Totals & 251758 & & 189634.7 & \\
\hline
\end{tabular}

Table 3. Total abundance $(\mathrm{N})$ and biomass (total wet wt) for the dominant deep-pelagic fish species caught along the southern slope of Georges Bank

\begin{tabular}{|lc|lc|}
\hline Species & N & Species & Total wet wt (g) \\
\hline Benthosema glaciale & 4904 & Nemichthys scolopaceus & $\mathbf{2 0 0 0 0 . 0}$ \\
Nemichthys scolopaceus & $\mathbf{1 4 8 7}$ & Stomias boa & 11919.0 \\
Stomias boa & 710 & Benthosema glaciale & 5570.7 \\
Myctophids (damaged) & 500 & Chauliodus sloani & 3997.0 \\
Chauliodus sloani & 395 & Merluccius bilinearis & 2332.3 \\
Serrivomer beanii & 212 & Sigmops elongatum & 1992.5 \\
Arctozenus risso & 206 & Serrivomer beanii & 1526.3 \\
Maurolicus weitzmani & 144 & Xenodermichthys copei & 763.7 \\
Scorpaenid juveniles & 133 & Etmopterus gracilispinis & 70.0 \\
\hline
\end{tabular}

fish abundance per species declined sharply with the next-most abundant fish, Stomias boa (Stomiidae), occurring at abundances approximately half that of $N$. scolopaceus (Table 3). The number of $N$. scolopaceus caught appeared to vary as a function of daylight (Tables 4 \& 5), with 3 of the 4 highest catches occurring at night, but this difference was not significant ( 2 tailed $t$-test, $\mathrm{p}>0.29$ ). Additionally, standard deviation was run for day and night catches (Table 4), showing that there was as much variability within day or night samples as there was between them.

\section{Trophic ecology of Nemichthys scolopaceus}

A total of 164 specimens were analyzed for gut contents. Seventy percent of the stomachs dissected (115 of 164) contained prey items. In the first 37 positive stomachs, 9 prey taxa were identified, with only 4 additional taxa identified in the remaining 78 stomachs. This pattern suggested that while additional specimens may yield a few new prey taxa, the sample size for this species was adequate to describe its trophic ecology (Hurtubia 1973).

Stomachs contained 13 prey taxa (Table 6), primarily decapod crustaceans ( $60 \%$ occurrence, $52 \%$ frequency) and euphausiids ( $54 \%$ occurrence, $47 \%$ frequency). There were many organisms that were not found in the guts (fishes, cephalopods, and larger crustaceans, such as crabs), even though they were collected from the environment. Ivlev's electivity index $(E)$ suggested that Nemichthys scolopaceus selected for macrocrustacea, defined as decapods, euphausiids, and lophogastrids $(+0.020$; Table 7$)$. It should be noted that smaller potential prey (e.g. copepods, amphipods, etc.) were not sampled with the gear used, so this index underestimates total prey selectivity. Fishes were completely selected against as prey $(E=-1)$, despite the fact that the most abundant fish, Benthosema glaciale, is comparable in size to the crustaceans taken and co-occurred with $N$. scolopaceus.

Our sampling could not discern diel changes in feeding activity (Fig. 3). Eels taken from the same trawls had varying levels of stomach fullness and differing degrees of prey digestion; i.e. the assemblage did not appear to feed synchronously. The averages of stomach fullness for day and night (1.34 and 
Table 4. Assemblage composition of micronektonic Crustacea and fishes sampled along the southern slope of Georges Bank. Recorded values are average ind. $\mathrm{h}^{-1}$, both day and night (standard deviation)

\begin{tabular}{|lcc|}
\hline & Day & Night \\
\hline Crustacea & & \\
Decapod & $10399(9232)$ & $19341(26316)$ \\
Euphausiid & $8491(9777)$ & $6720(7499)$ \\
Mysid & $6(8)$ & $110(220)$ \\
Fishes & & \\
Benthosema glaciale & $327(375)$ & $542(535)$ \\
Nemichthys scolopaceus & $89(77)$ & $244(220)$ \\
Stomias boa & $57(64)$ & $114(130)$ \\
Chauliodus sloani & $41(50)$ & $28(46)$ \\
Other myctophids & $55(63)$ & $135(105)$ \\
Other fishes & $130(121)$ & $95(26)$ \\
\hline
\end{tabular}

Table 5. Numbers of snipe eel Nemichthys scolopaceus captured according to solar cycle along the southern slope of Georges Bank. Eel abundance $=$ ind. $\mathrm{h}^{-1}$

\begin{tabular}{|lcr|}
\hline Station & $\begin{array}{l}\text { Solar } \\
\text { cycle }\end{array}$ & $\begin{array}{c}\text { Eel } \\
\text { abundance }\end{array}$ \\
\hline 4 & Day & 45.6 \\
5 & Night & 163.3 \\
6 & Night & 0.0 \\
10 & Day & 296.0 \\
12 & Day & 61.8 \\
14 & Night & 520.0 \\
16 & Day & 22.2 \\
19 & Day & 70.7 \\
20 & Day & 95.0 \\
23 & Day & 60.0 \\
24 & Day & 122.0 \\
25 & Day & 24.0 \\
26 & Night & 192.0 \\
27 & Day & 56.7 \\
28 & Day & 122.0 \\
\hline
\end{tabular}

Table 6. Number of prey items identified from Nemichthys scolopaceus $(\mathrm{n}=164)$ collected from the southern slope of Georges Bank

\begin{tabular}{|ccc|}
\hline & Stomach & Intestine \\
\hline Crustacea & 213 & 64 \\
Euphausiid & 103 & 25 \\
Meganyctiphanes norvegica & 23 & - \\
Decapoda & 93 & 27 \\
Sergestidae & 10 & - \\
Sergestes arcticus & 3 & - \\
Sergestes sp. & 2 & - \\
Sergia sp. & 1 & - \\
Caridean & 4 & - \\
Acanthephyra purpurea & 1 & - \\
Parapasiphaea sulcatifrons & 1 & - \\
Lophogastrida & 1 & - \\
Gnathophausia sp. & 1 & - \\
\hline
\end{tabular}

Table 7. Abundance and percent occurrence of prey groups in the water column and in stomach contents of Nemichthys scolopaceus, day and night combined, and Ivlev's electivity index values $(E)$ for 2 main prey groups. Macrocrustacea is defined as decapods, euphausiids, and lophogastrids. $\mathrm{N}=$ total number of specimens caught in trawls; $\mathrm{N}_{1}=$ total number of specimens within the gut

\begin{tabular}{|lcrrr|}
\hline & \multicolumn{2}{c|}{ Environment } & \multicolumn{2}{c|}{ Eel stomachs } \\
& $\mathrm{N}$ & $\%$ & $\mathrm{~N}_{1}$ & $\%$ \\
\hline Macrocrustacea & 241893 & 96 & 131 & 100 \\
Fishes & 9865 & 4 & 0 & 0 \\
Macrocrustacea & $E=0.020$ & & & \\
Fishes & $E=-1$ & & & \\
\hline
\end{tabular}

1.56 , respectively) were very similar, suggesting these eels do not feed at a specific time of day. The degree of digestion averages ( 3.36 for day and 3.76 for night) revealed that most eels collected had well-digested prey material in their stomachs no matter what time of day. Further, 12 of the 115 eels with positive stomachs contained multiple prey items exhibiting different states of digestion. These prey item combinations generally contained one 'fresh' prey item and one almost completely digested. The remaining eels contained either one fresh large prey item or a stomach containing mainly digested material.

\section{DISCUSSION}

\section{Diet composition}

Nemichthys scolopaceus apparently selects for macrocrustacea while ignoring other potential prey, either by choice or by morphological necessity (nonocclusible jaws). Of the 164 eels dissected, 135 were positive for gut contents (either stomach or intestine), all of which contained large pelagic crustaceans. Other possible prey, such as fishes, pelagic molluscs, and larger zooplankton, were absent from the specimens examined, even though they can appear in large mixed aggregations with $N$. scolopaceus (Auster et al. 1992). This agrees with prior findings that captured $N$. scolopaceus guts usually contain only crustacean prey items (Mead \& Earle 1970, Gartner 1981, Appelbaum 1982, Karmovskaya 1982, Hopkins et al. 1996, Bowman et al. 2000). Indeed, the high abundances of pelagic macrocrustacea $(96.9 \%$ of the total micronekton assemblage numbers) may be responsible for the high relative abundance of $N$. scolopaceus $(15.1 \%)$ at this, and other shelf-break study sites. 

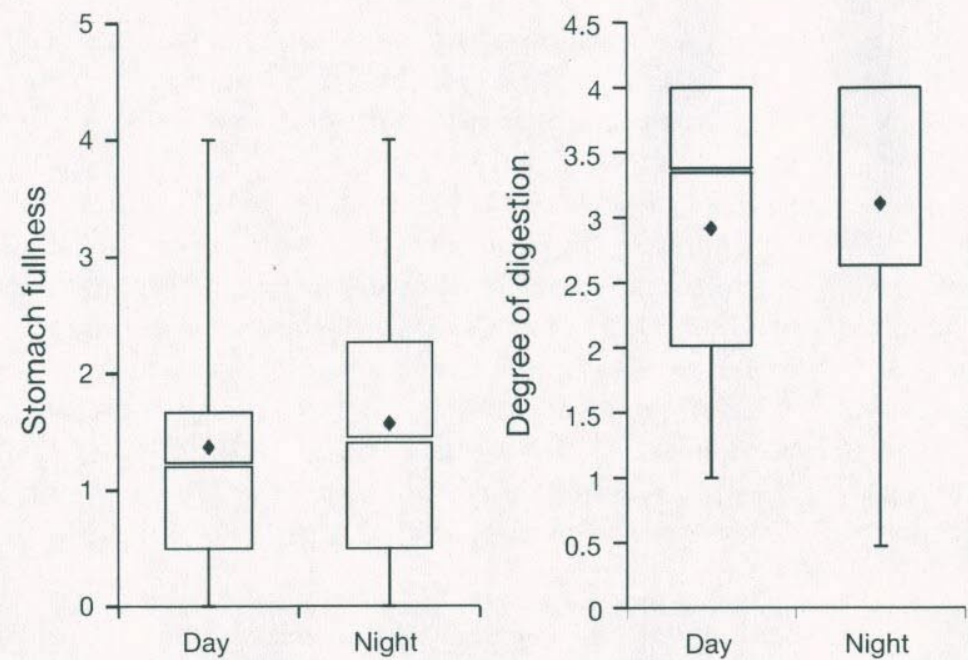

Fig. 3. Feeding chronology of Nemichthys scolopaceus. Stomach fullness of $0=$ empty stomach, while $4=$ a full and stretched stomach. Degree of digestion of 1 = recently ingested prey, while $4=$ well digested prey. Average per solar cycle designated with •

\section{Feeding chronology}

Feeding chronology (i.e. when during the diel cycle a fish feeds most actively) represents a key element of a species' trophic ecology. Vertical migration can play a large role in the feeding patterns of many deep-sea fishes, while others exhibit no change over the diel cycle (Merrett \& Roe 1974). In the case of Nemichthys scolopaceus, the shrimp prey are large enough that they would not necessarily clear the eel's stomach within a $24 \mathrm{~h}$ period (Pandian 1967a,b). Additionally, deep-sea fishes are known to have lower metabolic rates (Torres \& Somero 1988a,b). Digestion rates may be impacted by the colder water temperature at depth (Childress 1995) and lower oxygen levels at the oxygen minimum zone (Torres et al. 2012); due to this, digestion rates in deep-sea fishes should be lower. Therefore, this species could be feeding at certain times of the day, but chronology would be masked by long digestion times. This bias was found in Photostomias guernei (Stomiiformes: Stomiidae), another fish species feeding primarily on decapod shrimps (Sutton \& Hopkins 1996); these authors concluded that $P$. guernei feeds at various times of the day, and then digests prey over a period of more than one day. This long digestion time also holds for many other deep-sea predatory fishes that feed only infrequently and are often found with empty stomachs (Gartner et al. 1997). We might expect that $N$. scolopaceus feed mostly at night. Midwater shrimps migrate upwards at night (Foxton 1970a,b, Flock \& Hopkins 1992), thus concentrating their numbers by occupying a narrower depth stratum relative to daytime distributions. Shrimp predators could hypothetically increase their encounter rate with their prey at night and eat larger numbers of shrimp in a smaller area and time, thus increasing their energetic gains per expense. Conversely, daytime feeding eels might gain an advantage in that their migratory prey are 'recovering' from the previous night's migration, and are thus less active (and less able to avoid predation). This feeding pattern contrasts with the 'sit-and-wait' predation style adopted by most piscivorous deep-sea fishes that use lures (e.g. Stomiidae) to attract prey. This feeding pattern, along with the muscular body of Nemichthys, suggests this eel relies on active searching rather than passive luring to encounter and capture their prey. Concurrent are the findings of Karmovskaya (1982), which suggest that $N$. scolopaceus undergo a 'very active round-the-clock migration' associated with feeding. Moreover, a high consumption rate of shrimps by eels is suggested by the fact that the percentage of eels containing prey items in their stomachs was higher $(\sim 70 \%)$ than that previously reported for other top mesopelagic predators $(40 \%)$ (Sutton \& Hopkins 1996, Gartner et al. 1997).

\section{Feeding selectivity}

It was originally thought deep-sea environments would force fishes to be capable of eating any potential prey encountered (Gage \& Tyler 1991). At higher food densities, foragers would theoretically concentrate on the capture of more energetically valuable prey items. As prey abundance declines, the diet of most fishes would be expected to broaden (Hart 1989). However, this explanation may be overly simplistic. Some fishes may exhibit a low diversity diet simply because that prey item is the most prevalent in that particular area. Prey selection is also a function of the morphology of predator and prey. The jaw shape of Nemichthys scolopaceous appears specialized to catch decapod prey by means of antennal entrapment (Beebe \& Crane 1937, Mead \& Earle 1970, Karmovskaya 1982). Antennal entrapment, as described by Mead \& Earle (1970), hypothesizes that, based on the morphologically unique structure of the nemichthyid jaws and the fact that they are covered 
in multiple rows of villiform teeth, the 'hairy' antennae of passing shrimp species would become entangled, thus allowing for easy capture. This could be why $N$. scolopaceus does not consume fish species. As fish would not have these longer antennae, the eels may be morphologically unable to catch and ingest them. In comparison, the members of the eel genus Serrivomer have much shorter, occlusible jaws, and they have been found with shrimp, euphausiids, small crustaceans, fish, and cephalopods within their stomachs (Beebe \& Crane 1936, Geidner 2008). Lacking empirical data, our data provide circumstantial evidence corroborating this antennal entrapment hypothesis. Further, given the numerical dominance of macrocrustacea as potential prey, one could also infer that the feeding of piscivorous micronekton predators (e.g. most Stomiidae) that do not consume macrocrustacea is an even higher form of feeding selectivity (Sutton \& Hopkins 1996).

Post-capture ingestion ('net feeding') can potentially affect the observed diet patterns of some midwater fishes (Lancraft \& Robison 1980), particularly with regard to feeding selectivity. However, in the case of Nemichthys scolopaceus, net feeding was deemed an unlikely source of bias. This species has a long, fragile body and jaws that upon capture become entangled in the trawl mesh prior to the codend. This was observed during this study by one author (T. T. Sutton pers. obs.) while picking specimens from the trawls; most specimens were taken from the forenet and had broken necks. Further evidence against net feeding bias included: (1) most specimens with positive guts had diet items that were either somewhat digested or compressed and covered in a slime coating, and (2) the high degree of selectivity within the eel's diet (codends are crowded with a diverse array of potential prey). Thus, while acknowledging the potential for bias, we consider the data presented herein to represent the active, in situ feeding of the species.

\section{Pelagic eel and macrocrustacean linkage at the oceanic rim}

In this study, we sampled a total of 85 fish species and at least 5 major groups of crustaceans. Nemichthys scolopaceus stomach contents revealed 13 prey types, primarily species of euphausiid and decapod crustaceans. Other potential prey, such as fishes, squids, and larger zooplankton, were absent from the diet, suggesting a fairly selective 'macrocrustacivorous' feeding preference. Moreover, this eel is one of only a few mesopelagic fish predators of shrimps and euphausiids in the area, the others being relatively rare. Even though crustacean predators are few, the crustacean prey are not. Decapod crustaceans represent an important part of the mesopelagic fauna, in certain areas making up over one-third of the total micronekton biomass (Foxton \& Roe 1974). In the area sampled in this study, large species of euphausiids were also highly prevalent (e.g. Meganyctiphanes norvegica, one of the largest euphausiid species) (Greene et al. 1988). In a recent study focused on coastal and epipelagic fauna in the Gulf of Maine ecosystem, Johnson et al. (2011, p. 2) state:

Euphausiids, notably the carnivorous Meganyctiphanes norvegica, are important constituents in the diet of upper level carnivores in the GoMA.

These large euphausiid populations are thought to be a very important link in the food chain between plankton and pelagic fishes in the Georges Bank ecosystem (Greene et al. 1988). Euphausiids were one of the most highly consumed prey taxa identified for N. scolopaceus in this study.

The area studied here represents a transition zone between coastal and deep-sea environments, a region for which we know very little about carbon transport. The southern Georges Bank flank, characterized by a series of submarine canyons, is populated by abundant midwater fishes. Of that assemblage, Nemichthys scolopaceus ranked second in abundance and first in total fish biomass. Prior published studies of nemichthyid eels show low numbers (Hopkins et al. 1996, Sutton et al. 2008). Post \& Tesch (1982) even stated that for $N$. scolopaceus, 'samples of more than 5 specimens are exceptional.' We find that that this species not only dominates fish biomass in this location, but also, within the mesopelagic zone, Nemichthys appears to cycle a significant portion of the macrocrustacean biomass to higher trophic levels. The daily rations (amount of prey consumed per day, expressed as a \% of the predator's weight) of pelagic eels are unknown, but if their rations scale with other midwater fishes $(1-4 \%$, but probably on the higher end given their activity and muscularity), then shrimp predation by this single species could be the dominant higher trophic level interaction in this region, and possibly other outer continental shelf ecosystems.

Acknowledgements. The authors thank the invaluable contributions of M. Fogarty and J. Galbraith of the NOAA NMFS Northwest Fisheries Science Center for providing the research platform, which made this study possible, and for 
providing sampling information for distributional analyses. We also thank the crew of the FSV 'Delaware II' for their excellent shiptime services and the Harbor Branch Oceanographic Institute for research and laboratory space. GoMA is a Census of Marine Life project. Funding for J.N.F.-B. was provided by the Florida Atlantic University Biology Department and for T.T.S. by a grant from the National Science Foundation Ocean Sciences Division-Biological Oceanography Program (OCE 0623551).

\section{LITERATURE CITED}

Alwany M, Thaler E, Stachowitsch M (2003) Food selection in 2 corallivorous butterflyfishes, Chaetodon austriacus and C. trifascialis, in the northern Red Sea. Mar Ecol 24: 165-177

Anonymous (1979) Snipe-eels unravelled. Nature 278:307

- Appelbaum S (1982) Studies on food organisms of pelagic fishes as revealed by the 1979 North Atlantic Eel Expedition. Helgol Meeresunters 35:357-367

- Auster PJ, Griswold CA, Youngbluth MJ, Bailey TG (1992) Aggregation of myctophid fishes with other pelagic fauna. Environ Biol Fishes 35:133-139

Beebe W, Crane J (1936) Deep-sea fishes of the Bermuda Oceanographic Expeditions: No. 3-Family Serrivomeridae. Zoologica 20:53-102

Beebe W, Crane J (1937) Deep-sea fishes of the Bermuda Oceanographic Expeditions: Family Nemichthyidae. Zoologica 22:349-383

Bilecenoglu M, Kaya M, Irmak E (2006) First records of the slender snipe eel, Nemichthys scolopaceus (Nemichthyidae), and the robust cusk-eel, Benthocometes robustus (Ophidiidae), from the Aegean Sea. Acta Ichthyol Piscat 36:85-88

Bowman RE, Stillwell CE, Michaels WL, Grosslein MD (2000) Food of northwest Atlantic fishes and 2 common species of squid. NOAA Tech Memo NMFS-NE-155

- Castonguay M, McCleave JD (1987) Vertical distributions, diel and ontogenetic vertical migrations and net avoidance of leptocephali of Anguilla and other common species in the Sargasso Sea. J Plankton Res 9:195-214

- Childress JJ (1995) Are there physiological and biochemical adaptations of metabolism in deep-sea animals? Trends Ecol Evol 10:30-36

Company JB, Puig P, Sardà F, Palanques A, Latasa M, Scharek R (2008) Climate influence on deep sea populations. PLoS ONE 3:e1431

Cooper RA, Valentine P, Uzmann JR, Slater RA (1987) Submarine canyons. In: Backus $\mathrm{RH}$, Bourne DW (eds) Georges Bank. MIT Press, Cambridge, MA, p 52-63

- Fishelson L (1994) Comparative morphology of deep-sea eels, with particular emphasis on gonads and gut structure. J Fish Biol 44:75-101

Flock ME, Hopkins TL (1992) Species composition, vertical distribution, and food habits of the sergestid shrimp assemblage in the Eastern Gulf of Mexico. J Crustac Biol 12:210-223

- Foxton P (1970a) The vertical distribution of pelagic decapods (Crustacea: Natantia) collected on the Sond cruise 1965, II. The Caridea. J Mar Biol Assoc UK 50: 939-960

- Foxton P (1970b) The vertical distribution of pelagic decapods (Crustacea: Natantia) collected on the Sond cruise
1965, II. The Penaeidea and general discussion. J Mar Biol Assoc UK 50:961-1000

Foxton P, Roe HSJ (1974) Observations on the nocturnal feeding of some mesopelagic decapod Crustacea. Mar Biol 28:37-49

Gage JD, Tyler PA (1991) Deep-sea biology: a natural history of organisms at the deep-sea floor. Cambridge University Press, Cambridge

Gartner JV Jr (1981) Aspects of vertical distribution and ecology of the dominant meso- and bathypelagic fishes from the Norfolk Canyon Region. MA Thesis, College of William and Mary, Williamsburg, VA

Gartner JV Jr, Crabtree RE, Sulak KJ (1997) Feeding at depth. In: Randall DJ, Farrell AP (eds) Deep-sea fishes. Academic Press, San Diego, CA, p 115-193

Gartner JV Jr, Sulak KJ, Ross SW, Necaise AM (2008) Persistent near-bottom aggregations of mesopelagic animals along the North Carolina and Virginia continental slopes. Mar Biol 153:825-841

Geidner ME (2008) Spatial and trophic ecology of the sawtooth eel, Serrivomer beanii, a biomass-dominant bathypelagic fish over the northern mid-Atlantic ridge. MS Thesis, Florida Atlantic University, Boca Raton, FL

Gras R, Saint-Jean L (1982) Comments about Ivlev's electivity index. Rev Hydrobiol Trop 15:33-37

Greene CH, Wiebe PH, Burczynski J, Youngbluth MJ (1988) Acoustical detection of high-density krill demersal layers in the submarine canyons off Georges Bank. Science 241:359-361

Haedrich RL (1997) Distribution and population ecology. In: Randall DJ, Farrell AP (eds) Deep-sea fishes. Academic Press, San Diego, CA, p 79-114

- Hart PJB (1989) Predicting resource utilization: the utility of optimal foraging models. J Fish Biol 35(Suppl A): 271-277

- Hopkins TL, Sutton TT, Lancraft TM (1996) The trophic structure and predation impact of a low latitude midwater fish assemblage. Prog Oceanogr 38:205-239

Horn MH (1972) The amount of space available for marine and freshwater fishes. Fish Bull 70:1295-1297

Hurtubia J (1973) Trophic diversity measurement in sympatric predatory species. Ecology 54:885-890

Inoue JG, Miya M, Miller MJ, Sado T and others (2010) Deep-ocean origin of the freshwater eels. Biol Lett 6 : 363-366

> Islam HS, Hibino M, Tanaka M (2006) Distribution and dietary relationships of the Japanese temperate bass Lateolabrax japonicus juveniles with 2 contrasting copepod assemblages in estuarine nursery grounds in the Ariake Sea, Japan. J Fish Biol 68:569-593

Ivlev VS (1961) Experimental ecology on the feeding of fishes. Yale University Press, New Haven, CT

Johnson CL, Runge JA, Curtis KA, Durbin EG and others (2011) Biodiversity and ecosystem function in the Gulf of Maine: pattern and role of zooplankton and pelagic nekton. PLoS ONE 6:e16491

Karmovskaya ES (1982) Systematics and some ecology of the snipe eels of the family Nemichthyidae. Proc PP Shirshov Inst Oceanol 118:151-161 (in Russian with English abstract)

Kelly NE, Shea EK, Metaxas A, Haedrich RL, Auster PJ (2010) Biodiversity of the deep-sea continental margin bordering the Gulf of Maine (NW Atlantic): relationships among sub-regions and to shelf systems. PLOS ONE 5: e13832 
Lancraft TM, Robison BH (1980) Evidence of post-capture ingestion by midwater fishes in trawl nets. Fish Bull 77 : 713-715

Marshall NB, Merrett NR (1977) The existence of a benthopelagic fauna in the deep-sea. In: Angel MV (ed) A voyage of discovery. George Deacon 70th anniversary Vol. Suppl Deep-Sea Res 24:483-497

- Mcllwain JL, Jones GP (1997) Prey selection by an obligate coral-feeding wrasse and its response to small-scale disturbance. Mar Ecol Prog Ser 155:189-198

Mead GW, Earle SA (1970) Notes on the natural history of snipe eels. Proc Calif Acad Sci 99-103

Merrett NR (1986) Biogeography and the oceanic rim: a poorly known zone of ichthyofaunal interaction. Pelagic Biogeography-Proc of an Int Symposium. UNESCO Tech Pap Mar Sci 49:201-209

Merrett NR, Roe HSJ (1974) Patterns and selectivity in the feeding of certain mesopelagic fishes. Mar Biol 28: 115-126

Miller MJ, McCleave JD (1994) Species assemblages of leptocephali in the Subtropical Convergence Zone of the Sargasso Sea. J Mar Res 52:743-772

Moore JA, Vecchione M, Collette BB, Gibbons R and others (2001) Biodiversity of Bear Seamount, New England seamount chain: results of exploratory trawling. J Northwest Atl Fish Sci 31:363-372

Nielsen JG, Smith DG (1978) The eel family Nemichthyidae (Pisces, Anguilliformes). Dana Report No. 88

Pandian TJ (1967a) Intake, digestion, absorption, and conversion of food in the fishes Megalops cyprinoides and Ophiocephalus striatus. Mar Biol 1:16-32

- Pandian TJ (1967b) Transformation of food in the fish Megalops cyprinoides. I. Influence of quality of food. Mar Biol 1:60-64

Porteiro FM, Sutton TT (2007) Midwater fish assemblages and seamounts. In: Pitcher TJ, Morato T, Hart PJB, Clark MR, Haggan N, Santos RS (eds) Seamounts: ecology, fisheries and conservation. Blackwell Publishing, Oxford, p 101-116

Post A, Tesch FW (1982) Midwater trawl catches of adolescent and adult anguilliform fishes during the Sargasso Sea Eel Expedition 1979. Helgol Meeresunters 35: 341-356

- Reid SB, Hirota J, Young RE, Hallacher LE (1991) Mesopela-

Editorial responsibility: Paul Snelgrove,

St. John's, Newfoundland and Labrador, Canada gic-boundary community in Hawaii: micronekton at the interface between neritic and oceanic ecosystems. Mar Biol 109:427-440

Ribeiro DFO, Nuñer APO (2008) Feed preferences of Salminus brasiliensis (Pisces, Characidae) larvae in fish ponds. Aquaculture 274:65-71

Robison BH (2004) Deep pelagic biology. J Exp Mar Biol Ecol 300:253-272

Smith DG, Nielsen JG (1989) Family Nemichthyidae: snipe eels. In: Böhlke EB (ed) Fishes of the western North Atlantic, Part 9, Vol 1. Sears Foundation for Marine Research, New Haven, CT, p 441-459

Smith DG, Tighe KA (2002) Snipe eels. Family Nemichthyidae. In: Collette BB, Klein-MacPhee G (eds) Fishes of the Gulf of Maine. 3rd edn. Smithsonian Institute Press, Washington, DC, p 100-101

Strauss RE (1979) Reliability estimates for Ivlev's electivity index, the forage ratio and a proposed linear index of food selection. Trans Am Fish Soc 108:344-352

Sutton TT, Hopkins TL (1996) Trophic ecology of the stomiid (Pisces: Stomiidae) fish assemblage of the eastern Gulf of Mexico: strategies, selectivity and impact of a top mesopelagic predator group. Mar Biol 127:179-192

Sutton TT, Porteiro FM, Heino M, Byrkjedal I and others (2008) Vertical structure, biomass and topographic association of deep-pelagic fishes in relation to a mid-ocean ridge system. Deep-Sea Res II 55:161-184

Torres JJ, Somero GN (1988a) Metabolism, enzymic activities and cold adaptation in Antarctic mesopelagic fishes. Mar Biol 98:169-180

Torres JJ, Somero GN (1988b) Vertical distribution and metabolism in Antarctic mesopelagic fishes. Comp Biochem Physiol 90B:521-528

- Torres JJ, Grigsby MD, Clarke ME (2012) Aerobic and anaerobic metabolism in oxygen minimum layer fishes: the role of alcohol dehydrogenase. J Exp Biol 215: 1905-1914

Webb TJ, Vanden Berghe E, O'Dor R (2010) Biodiversity's big wet secret: the global distribution of marine iological records reveals chronic under-exploration of the deep pelagic ocean. PLoS ONE 5:e10223

Wiebe PH, Boyd S, Cox JL (1975) Relationships between zooplankton displacement volume, wet weight, dry weight, and carbon. Fish Bull 73:777-786

Submitted: February 6, 2013; Accepted: December 18, 2013

Proofs received from author(s): March 24, 2014 